\title{
GAMBARAN STRATEGI PUSKESMAS CIBUNGBULANG KABUPATEN BOGOR DALAM MENURUNKAN ANGKA STUNTING TAHUN 2019
}

\author{
Siti Wahiyah', Eny Dwimawati², Indira Chotimah ${ }^{3}$ \\ ${ }^{1}$ Konsentrasi Manajemen Pelayanan Kesehatan, Program Studi Kesehatan Masyarakat, Fakultas Ilmu Kesehatan, \\ Universitas Ibn Khaldun Bogor. Jl. K.H. Sholeh Iskandar Raya Km. 2, Kedung Badak, Bogor 16162, Jawa Barat. \\ Email : swahiyah@gmail.com \\ ${ }^{2,3}$ Konsentrasi Manajemen Pelayanan Kesehatan, Program Studi Kesehatan Masyarakat, Fakultas Ilmu Kesehatan, \\ Universitas Ibn Khaldun Bogor. Jl. K.H. Sholeh Iskandar Raya Km. 2, Kedung Badak, Bogor 16162, Jawa Barat.
}

\begin{abstract}
Abstrak
Pada tahun 2017 Indonesia termasuk ke dalam negara ketiga dengan prevalensi tertinggi di regional Asia Tenggara/ South-East Asia Regional (SEAR). Rata - rata prevalensi balita stunting di Indonesia tahun 2005-2017 adalah 36,4\%. Di Jawa Barat pada tahun 2017 prevalensi Stunting menunjukan angka sebesar 29,2\%, hal ini menunjukan bahwa belum mencapai target Rencana Pembangunan Jangka Menengah Nasional (RPJMN) tahun 2019 yaitu 28\%. Tujuan penelitian ini adalah untuk mengetahui Strategi Puskesmas Cibungbulang Kabupaten Bogor dalam menurunkan angka stunting tahun 2019. Penelitian ini menggunakan metode kualitatif dengan teknik pengumpulan data menggunakan wawancara mendalam kepada informan dan telaah dokumen. Populasi dalam penelitian ini adalah tenaga kesehatan Puskesmas Cibungbulang. penelitian ini terdiri dari 8 orang informan dengan 1 informan kunci dan 7 informan pendukung. Kesimpulan penelitian ini adalah strategi yang dilakukan Puskesmas Cibungbulang dalam melakukan pencegahan dan penanganan masalah stunting sudah baik tetapi belum berjalan maksimal karena desa lokasi khusus belum terbebas dari masalah stunting. Puskesmas selalu memaksimalkan penanganan masalah stunting tersebut dengan program-program yang telah di rencanakan.
\end{abstract}

Kata Kunci : Strategi, Stunting, Gizi.

\section{PENDAHULUAN}

Pembangunan kesehatan menurut Rencana Pembangunan Jangka Menengah Nasional (RPJMN) periode 2015-2019 adalah program Indonesia sehat dengan sasaran meningkatkan derajat kesehatan dan status gizi masyarakat melalui upaya kesehatan dan pemberdayaan masyarakat yang didukung dengan perlindungan finansial dan pemerataan pelayanan kesehatan.

Program Indonesia sehat dilaksanakan dengan 3 pilar utama yaitu paradigma sehat, penguatan pelayanan kesehatan dan jaminan kesehatan nasional: (1) pilar paradigma sehat di lakukan dengan strategi pengarusutamaan kesehatan dalam pembangunan, penguatan promotive, preventif dan pemberdayaan masyarakat; (2) penguatan pelayanan kesehatan kesehatan dilakukan dengan strategi peningkatan akses pelayanan kesehatan, optimalisasi sistem rujukan dan peningkatan mutu pelayanan kesehatan; (3) sementara itu jaminan kesehatan nasional dilakukan dengan strategi perluasan sasaran dan benefit serta kendali mutu dan kendali biaya. 
Kejadian balita pendek atau biasa disebut dengan stunting merupakan salah satu masalah gizi yang dialami oleh balita di dunia saat ini. Kondisi ini diukur dengan panjang atau tinggi badan yang lebih dari minus dua standar deviasi median standar pertumbuhan anak dari $W H O$. Balita stunting termasuk masalah gizi kronik yang disebabkan oleh banyak faktor seperti kondisi sosial ekonomi, gizi ibu saat hamil, kesakitan pada bayi, dan kurangnya asupan gizi pada bayi. Balita stunting di masa yang akan datang akan mengalami kesulitan dalam mencapai perkembangan fisik dan kognitif yang optimal (Kemenkes, 2018).

Data prevalensi balita stunting yang dikumpulkan World Health Organiztion (WHO), pada tahun 2017 Indonesia termasuk ke dalam negara ketiga dengan prevalensi tertinggi di regional Asia Tenggara/ South-East Asia

Regional (SEAR). Rata - rata prevalensi balita stunting di Indonesia tahun 2005-2017 adalah 36,4\% (WHO, 2017). Tahun 2018 Indonesia menempati urutan ke 5 dunia. Hal ini menunjukkan bahwa Indonesia merupakan negara dengan stunting yang tinggi bahkan prevalensinya diatas standar WHO yaitu sebesar 20\% (Riskesdas, 2018).

Kejadian balita Stunting (pendek) merupakan masalah gizi utama yang dihadapi Indonesia. Berdasarkan data Pemantauan Status Gizi (PSG) selama tiga tahun terakhir, bahwa pendek memiliki prevalensi tertinggi dibandingkan dengan gizi kurang, kurus, dan gemuk. Prevalensi balita pendek mengalami peningkatan dari tahun 2016 yaitu 27,5\% menjadi 29,6\% pada tahun 2017. Disamping itu prevalensi balita sangat pendek dan pendek usia 0-59 bulan di Indonesia tahun 2017 adalah 9,8\% dan 19,8\%. Kondisi ini meningkat dari tahun sebelumnya yaitu prevalensi balita sangat pendek sebesar 8,5\% dan balita pendek sebesar 19\% (Kemenkes, 2018). Tahun 2017 di Jawa Barat prevalensi Stunting menunjukan angka sebesar 29,2\%, hal ini menunjukan bahwa masih tingginya angka stunting dan belum mencapai target Rencana Pembangunan Jangka Menengah Nasional (RPJMN) tahun 2019 yaitu 28\% (Dinkes, 2017).

Berdasarkan laporan Pemantauan Gizi Nasional (PSG) tahun 2017, prevalensi stunting di Kabupaten Bogor mencapai 28,5\% yang nilai karakteristik masalah gizinya masih kronis.

Kabupaten Bogor merupakan salah satu kabupaten yang menjadi lokasi intervensi dalam menekan angka stunting di Jawa Barat, karena Berdasarkan pada data Puskesmas Cibungbulang tahun 2018 menunjukan bahwa angka stunting diwilayah kerja Puskesmas Cibungbulang adalah 354 balita umur 24-59 bulan dan 162 balita pada umur 0-23 bulan yang mengalami stunting di 7 desa/kelurahan. Desa dengan stunting tertinggi yaitu desa Cibatok II yaitu 40 balita stunting usia 24-59 bulan. Desa Cibatok II juga merupakan salah satu daerah perwakilan model di Pulau Jawa Barat untuk membantu penanganan stunting dengan program Kampung Anak Sejahtera (KAS) yang ditangani langsung oleh Kementerian Pemberdayaan Perempuan dan Perlindungan Anak (KPPA). Puskesmas Cibungbulang juga merupakan Center Klinik Gizi di wilayah Bogor Barat. 


\section{METODE PENELITIAN}

termasuk salah satu Kabupaten dengan prevalensi yang tinggi (Kemenkes, 2017).

Tabel 1. Informan Penelitian

\begin{tabular}{|c|c|c|}
\hline No & Jabatan & $\begin{array}{l}\text { Jumlah } \\
\text { Informan }\end{array}$ \\
\hline $\begin{array}{l}1 . \\
2 .\end{array}$ & $\begin{array}{l}\text { Kepala Puskemas } \\
\text { Tenaga Gizi/Nutrisionis }\end{array}$ & \\
\hline 3. & Bidan Desa & \\
\hline 4. & Tenaga Kesehatan & \\
\hline 5. & Kader & \\
\hline & $\begin{array}{c}\text { Kesehatan Masyarakat } \\
\text { TOTAL }\end{array}$ & \\
\hline
\end{tabular}

\section{Hasil Penelitian}

\section{Karakteristik Informan}

Tabel 2. Karakteristik Informan

\begin{tabular}{|c|c|c|c|c|c|}
\hline No & Informan & $\begin{array}{c}\text { Pendidik an } \\
\text { Terakhir }\end{array}$ & Jabatan & $\begin{array}{c}\text { Lama } \\
\text { Menjabat }\end{array}$ & Umur \\
\hline 1. & Informan 1 & Profes Dokter & $\begin{array}{c}\text { Kepala } \\
\text { Puskesmas }\end{array}$ & 5 Tahun & 44 Tahun \\
\hline 2. & Informan 2 & D3 Gizi & $\begin{array}{c}\text { Tenaga } \\
\text { Pelaksana } \\
\text { Gizi }\end{array}$ & 24 Tahun & 51 Tahun \\
\hline 3. & Informan 3 & $\begin{array}{c}\text { D3 } \\
\text { Kebidanan }\end{array}$ & $\begin{array}{c}\text { Bidan Desa } \\
\text { 13 Tahun }\end{array}$ & 45 Tahun \\
\hline 4. & Informan 4 & $\begin{array}{c}\text { Sesehatan } \\
\text { Masyarakat }\end{array}$ & $\begin{array}{c}\text { Kenaga } \\
\text { Lingkunga } \\
\text { n }\end{array}$ & 5 Tahun & 43 Tahun \\
\hline 5. & Informan 5 & $\begin{array}{c}\text { Keperawatan } \\
\text { dan Profesi }\end{array}$ & $\begin{array}{c}\text { Perawat } \\
\text { Muda }\end{array}$ & 10 Tahun & 40 Tahun \\
\hline 6. & Informan 6 & SMP & $\begin{array}{c}\text { Kader } \\
\text { Kesehatan }\end{array}$ & 11 Tahun & 37 Tahun \\
\hline 7. & Informan 7 & SMA Paket C & $\begin{array}{c}\text { Kader } \\
\text { Kesehatan }\end{array}$ & 5 Tahun & 33 Tahun \\
\hline 8. & Informan 8 & SMP & $\begin{array}{c}\text { Kader } \\
\text { Kesehatan }\end{array}$ & 15 Tahun & 54 Tahun \\
\hline
\end{tabular}

Penelitian ini dilakukan di Puskesmas Cibungbulang Kabupaten Bogor pada bulan April sampai bulan Juli 2019. Jenis penelitian ini merupakan penelitian kualitatif yang bersifat deskriptif. Teknik pengumpulan data pada penelitian ini yaitu dengan wawancara mendalam, telaah dokumen dan observasi. Teknik pengambilan informan pada penelitian ini yaitu dengan menggunakam dua prinsip yaitu kesesuaian dan kecukupan (Anggita, 2012).

\section{Input}

Input dalam penelitian ini yaitu terdiri dari sumber daya manusia (SDM), pembiayaan, metode, alat, dan fasilitas.

Hasil wawancara mengenai SDM informan mengatakan bahwa SDM dalam penanganan dan pencegahan stunting terdiri dari petugas gizi, bidan desa, petugas kesehatan masyarakat, 
petugas kesehatan lingkungan, dan petugas pemberantas korupsi. Seperti yang diungkapkan berikut:

“...banyak kan kita eeee lintas program dan lintas sektoral. Lintas program kaitannya dengan eeee tenaga pelaksana gizi, kemudian bidan desa, bidan koordinator, promosi kesehatan, Pemberantasan Penyakit Menular (P2M), kesehatan lingkungan dan kesehatan masyarakat. Untuk tenaga sudah mencukupi.." (Informan 2)

“...kalau saya untuk di Puskesmas udah mencukupi. Ada petugas lain kayak program KIA nya, kesling semua menunjang termasuk kesmas.." (Informan 3)

Pada pembiayaan untuk pencegahan dan penanganan stunting di puskesmas Cibungbulang bersumber dari dana APBD Kabupaten Bogor dan BOK. Adapun dana dari pihak ke tiga yaitu CSR, Kependudukan, IPB. Berikut kutipan wawancaranya:

“...dari Dinas Kesehatan Kabupaten Bogor melalui BOK..” ( Informan 5)

“....kemarin juga stunting pembiayaannya tidak hanya dari perusahaan CSR termasuk dari eee dari IPB, kemudian dariiii eee kependudukan ada berbagai sumber sih untuk menangani lokus stunting.." (Informan 2)

Jawaban dari kedua informan tersebut diperkuat dengan jawaban informan kunci, sebagai berikut:

“....nah pembiayaan penanganan stunting eeee kita bersumber dari eeee APBD Kabupaten Bogor yah kalau Puskesmas itu dengan BOK tapi BOK eeee kita hanya perjadin (perjalanan dinas) petugas untuk memberikan penyuluhan kelapangan nah untuk sementara dana yang untuk penanganan stunting itu sendiri ada tersedia dari dana desa.." (Informan 2)

Metode yang digunakan Puskesmas dalam pencegahan stunting yaitu dengan dua pendekatan yaitu pendekatan sensitif dan spesifik. Pendekatan spesifik ini lebih kepada kegiatan penyuluhan, pemberian makanan tambahan serta kunjungan rumah, penyuluhan kepada warga diwilayah Kerja Puskesmas. Berikut kutipan wawancaranya:

“...penanganan sendiri 2 sebenarnya ada penanganan upaya sensitive dan spesifik. Metodenya ada beberapa bisa penyuluhan ya kalau dengan kita metodenya ada beberapa bisa penyuluhan ya kalau dengan upaya spesifik dengan penyuluhan kemudian dengan pemberian makanan tambahan ya eee kemudian kita kunjungan rumah itu aja.." (Informan 2)

Alat yang digunakan dalam mengukur status gizi di Puskesmas Cibungbulang yaitu timbangan berat badan, baby scale, pengukur tinggi badan dan pengukur lingkar lengan untuk ibu hamil. Berikut kutipan wawancaranya:

“....alatnya kita menggunakan apa tinggi badan, terus timbangan ya kemudian menggunakan lingkar lengan atas untuk ibu hamil takutnya KEK sehingga lahirnya tidak pendarahandan sebagainya..." (Informan 2)

"....alatnya udah menurut saya udah lumayan tercukupilah. Kayak ada untuk pengukuranya, sama untuk berat badannya, tinggi badannya, semua..”(Informan 3) 
“....kayak timbangan apasih pengukur tinggi badan idealnya gimana, biasa.. lingkar kepala kayak gitu kan, lingkar lengan . karena untuk pengukuran bayinya.." (Informan 5)

Jawaban dari kedua informan tersebut diperkuat oleh informan lainnya. Berikut kutipan wawancaranya:

“....hanya ukuran dan penimbangan. Timbangan dan tinggi badan. Selain itu kalau yang diposyandu.." (Informan 7)

“....alatnya udah cukup kayak pengukur tinggi badan, berat badan yang bayinya itu baby scale ya.." (Informan 8)

Fasilitas dalam pencegahan dan penangan stunting di Puskesmas Cibungbulang masih belum mencukupi seperti dibagian media informasi poster dan leaflet mengenai stunting belum terdapat di Puskesmas Cibungbulang. Berikut kutipan wawancaranya:

“....belum tercukupi. Kalau untuk di desa belum yah.kalau di Puskesmas udah. Posternya kan belum terpampang banyak tiap-tiap ini, maksudnya yah berpartisipasi biar masyarakat lebih paham, bantuan udah banyak soalnya." (Informan 3)

"....kalau untuk dari sarana mungkin belum cukup yah. Ada sih sarana di desa ada ambulance desa.." (Informan 7)

\section{Proses}

Proses dalam penelitian ini meliputi visi dan misi, sasaran, strategi, implementasi (program, kebijakan, prosedur, struktur dan tugas/ tanggung jawab) dan hasil.

Berdasarkan wawancara dengan informan didapatkan bahwa visi dan misi pencegahan dan penanganan stunting yaitu terbebasnya lokasi khusus dari stunting tahun 2020. Berikut kutipan wawancaranya:

“....kita visinya pokoknya eeee desa lokus bebas dari stunting sampai 2020 rencananya... iya pokoknya desa lokus tidak ada stunting sehingga kedepan tidak ada lagi desa yang masuk desa lokus stunting...misinya eeee ya meningkatkan kesejahteraan masyarakat, trus kecerdasan juga meningkat."” (Informan 2)

Sasarannya yaitu lebuh ditekankan kepada penderita stunting dengan strategi-strategi Puskesmas Cibungbulang dengan pengimplementasikan program-program yang telah di rencanakan oleh Puskesmas Cibungbulang. Berikut kutipan wawancaranya:

“....ya kalau bantuan tadi itu secara kewajiban khusus untuk yang stunting tetapi juga kita sekalian dari program gizinya sendiri ialah memberantas eeee apa dengan mencari orang yang belum terkena stunting tetapi diduga dengan ciri- ciri khususnya kearah sana.."(Informan 1)

Strategi yang dilakukan Puskesmas Cibungbulang yaitu dengan memberikan edukasi dan penyuluhan, mendeteksi secara dini, pemantauan

1.000 HPK serta pemberian makanan tanbahan bagi penderita stunting. Berikut kutipan wawancaranya:

“...edukasi yang diberikan oleh staff kita baik dalam posyandu, balai desa, Puskesmas, 
Kecamatan, maupun disekolah. Memberikan edukasi terkait pemberian makanan tambahan serta pencegahan penyakit yang bisa dilkaukan sendiri.." (Informan 1)

Program yang dilakukan Puskesmas Cibungbulang dalam pencegahan stunting yaitu dengan mengadakan kelas ibu, penyuluhan, pemerikasaan dahak serta hygiene sanitasi makanan dan minuman. Berikut kutipan wawancaranya:

“...ya misalnya program Puskesmas yang kelas ibu, penyuluhan gizi, pemberian makanan tambahan kepada balita stunting. Dari P2M juga ada ee pemeriksaan dahak takut terjadi suspek TB paru. Kemudian dari kesling yaitu ada jumantik, terus penyediaan air bersih. Lalu ada juga pemberdayaan masyarakat mengenal stunting yah. Untuk sekarang ini lebih kepada ee pemberian makanan tambahan (PMT) $30 \%$ kepada ee pemberdayaan masyarakat, 70\% kepada pemberian makanan tambahan.." (Informan 2)

Hasil wawancara menunjukan bahwa kebijakan yang dilakukan yaitu dengan melibatkan semua pihak baik pihak lintas program maupun lintas sektoral. Berikut kutipan wawancaranya:

“...harus mendukung. Contohnya saja kita bekerjasama dengan dinas kesehatan juga dengan perusahaan- perusahaan dari pemerintah pun sangat mendukung contohnya saja dengan Pemberian Makanan Tambahan (PMT) yang diturunkan langsung per 6 bulan sekali.." (Informan 1)

Hasil wawancara menunjukkan bahwa prosedur yang dilakukan yaitu dari program penimbangan balita yang nantinya hasil nya akan divalidasi oleh Puskesmas. Berikut kutipan wawancaranya:

“....prosedurnya kita dengan bulan penimbangan balita harus 100\% balita diukur berat badan dan tinggi badannya dan juga pemberian vitamin A. dari hasil penimbangan balita kemudian laporan dari mereka kita validasi kembali.." (Informan 2)

Hasil wawancara menunjukkan bahwa struktur organisasi di Puskesmas Cibungbulang sudah terlibat khususnya dilintas program dan sektoral. Berikut kutipan wawancaranya:

“....sudah.. kalau Cibungbulang sendiri sudah. karena penanganan memang stunting ini tidak bisa satu pihak saja. Bahkan diluar lintas sektor juga sudah harus ikut campur..."(Informan 1)

Hasil wawancara menunjukkan bahwa tanggung jawab petugas kesehatan di Puskesmas Cibungbulang sudah baik. Berikut kutipan wawancaranya:

“....kalau Puskesmas sih kalau menurut saya cukup maksimal.. untuk tugas dari tenaga gizi sendiri dimana kita melapor kepada pimpinan bahwa ada lokus tunting diwilyah kerja Puskesmas setelah itu kita sosialisasi ditingkat kecamatan sehingga mereka ikut berperan dalam penanganan stunting ini.." (Informan 2) 


\section{Output}

Hasil penelitian menunjukkan bahwa gambaran strategi Puskesmas Cibungbulang dalam menurunkan angka stunting yaitu dengan deteksi dini, adanya kelas ibu hamil, penyuluhan kepemilikan jamban dari segi kesehatan lingkungan. Berikut kutipan wawancaranya:

“...kalau untuk sedini mungkin ya itu kelas ibu hamil dimana diberikan penyuluhan. Lalu dengan pemberian makanan tambahan yaitu makanan gizi seimbang..” (Informan 3) “...penyuluhan kepemilikan jamban kepada masyarakat serta sanitasi air, dari kesling pun ada infeksi rumah dimana dilihat dari saranaair bersihnyadilihat dari sumur galian apakah memenuhhi syara t atau tidak.." (Informan 4)

\section{PEMBAHASAN}

\section{Input}

Puskesmas Cibungbulang memiliki Sunber Daya Manusia (SDM) gizi 1 orang hal ini menunjukkan masih belum memenuhi standar Permenkes RI Nomor 75 Tahun 2014 tentang Puskesmas dimana standar gizi di Puskesmas kategori rawat inap yait 2 orang akan tetapi di Puskesmas Cibungbulang hanya memiliki 1 orang. Pembiayaan dalam pencegahan dan penanganan stunting bersumber dari dana APBD Dinas Kesehatan Kabupaten Bogor dan BOK serta ada dari pihak ke tiga yaitu CSR, IPB dan kependudukan. Metode yang dilakukan Puskesmas Cibungbulang dalam pencegahan stunting yaitu dengan dua pendekatan yaitu spesifik dan sensitif. Adapun alat yang ada di Puskesmas Cibungbulang untuk mengukur status gizi meliputi timbangan berat badan, baby scale, pengukur tinggi badan dan alat ukur lingkar lengan. Fasilitas dalam pencegahan dan penanganan stunting di Puskesmas Cibungbulang belum tercukupinya media informasi seperti poster dan leaflet khusus stunting.

\section{Proses}

visi dan misi Puskesmas Cibungbulang mengenai stunting ini yaitu menjadikan lokasi khusus terbebas dari stunting tahun 2020 dengan sasaran lebih ditekankan kepada penderita stunting melalui strategi- strategi yang dilakukan Puskesmas Cibungbulang seperti melakukan deteksi dini, terhadap remaja,penyuluhan, kelas ibu. Program yang dilakukan yaitu program kelas ibu, pemberian makanan tambahan, pemerikasaan dahak serta menggalakan kepemilikan jamban. Kebijakan dalam penanganan stunting ini sangat didukung oleh pihak Puskesmas dan Pemerintah dengan adanya Peraturan undang-undang tahun 2012 tentang pangan. Prosedur pencegahan dan penanganan stunting di mulai dari data penimbangan balita disetiap desa lalu dilaporkan dan akan divalidasi oleh pihak Puskesmas. Komponen struktur serta tanggung jawab semua petugas Puskesmas sudah berjalan baik dan melakukan tugas sesuai jobdesk yang telah disepakati.

\section{Output}

Hasil penelitian menunjukkan bahwa gambaran startegi Puskesmas Cibungbulang dalam menurunkan angak stunting yaitu dengan melakukan pelaksanaan berbagai program seperti program kelas ibu, kelas bayi balita yang ingin digencarkan, disamping itupula program deteksi dini dimana dengan pemantauan di 1000 hari pertama kehidupan. Puskesmas juga sangat mendukung adanya program PIS-PK yang diadakan oleh pemerintah karena dengan PIS-PK ini sangat membantu Puskesmas dalam melakukan pendataan seperti pada kesehatan lingkungan yang sedang mengalakkan kepemilikan jamban kepada masyarakat yang belum 
mempunyai ini kaitannya dengan masalah sanitasi.

\section{KESIMPULAN}

a. Jumlah sumber daya manusia untuk pencegahan dan penanganan stunting belum mencukupi untuk tenaga gizi menurut Permenkes No 75 tahun 2014 bahwa standar tenaga gizi di Puskesmas kawasan perkotaan dan kategori Puskesmas rawat inap yaitu 2 orang tetapi di Puskesmas Cibungbulang hanya ada 1 orang. Pembiayaan untuk pencegahan dan penanganan stunting di Puskesmas Cibungbulang bersumber dari dana APBD Dinas Kesehatan Kabupaten Bogor dan BOK. Tidak hanya dari pemerintah tetapi ada dari pihak ketiga yang membantu untuk pembiayaan pencegahan dan penanganan stunting tersebut seperti CSR, IPB, kependudukan. Metode yang dilakukan Puskemas Cibungbulang untuk pencegahan dan penanganan stunting yaitu dengan dua pendekatan yaitu sensitif dan spesifik. Alat yang digunakan untuk menilai status gizi yang digunakan di Puskesmas Cibungbulang yaitu timbangan berat badan, pengukur tinggi badan, dan alat untuk mengukur lingkar lengan. Fasilitas yang ada di Puskesmas Cibungbulang belum mencukupi, belum adanya media informasi promosi kesehatan khususnya mengenai masalah stunting seperti poster-poster, leaflet.

b. Visi dan misi Puskesmas Cibungbulang dalam pencegahan dan penanganan stunting yaitu menjadikan lokus terbebas dari stunting tahun 2020 dengan tujuan untuk meningkatkan kesejahteraan masyarakat dan meningkatkan kecerdasan. Sasaran dari program-program yang dilakukan Puskesmas Cibungbulang yaitu lebih ditekankan kepada penderita stunting. Strategi yang dilakukan Puskesmas Cibungbulang yaitu dengan melakukan deteksi dini terhadap remaja dengan mengadakan penyuluhan, mengadakan kelas ibu serta pemantauan 1.000 hari pertama kehidupan. Program- program yang dilakukan Puskesmas Cibungbulang dalam pencegahan stunting dari segi gizi yaitu program kelas ibu, Pemberian Makanan tambahan (PMT), kelas balita, sedangkan dari Pemberantasan Penyakit Menular (P2M) yaitu pemeriksaan dahak. Program dari kesehatan lingkungan yaitu program jumantik, penyediaan air bersih, pemantauan depot air minum serta program kepemilikan jamban. Kebijakan Puskesmas Cibungbulang dalam pencegahan dan penanganan stunting tersebut sangat mendukung dengan melibatkan beberapa lintas program yang ada di Puskesmas Cibungbulang, disamping itu kebijakan pemerintah pun sangat mendukung dengan adanya peraturan-peraturan pemerintah terkait penanganan gizi masyarakat. Prosedur yang dilakukan Puskesmas Cibungbulang dalam penanganan dan pencegahan stunting yaitu dengan bulan penimbangan balita dan selanjutnya dilakukan validasi ulang. Komponen struktur Puskesmas Cibungbulang dalam penanganan dan pencegahan stunting sudah bekerjasama dengan baik. Implementasi mengenai tugas /tanggung jawab petugas ksehatan dalam penanganan dan pencegahan stunting sudah baik dan sudah maksimal dalam menjalankan tugasnya. 


\section{DAFTAR PUSTAKA}

Almatsier, S. 2009. Prinsip Dasar Ilmu Gizi. Jakarta: Gramedia

Azwar A. 2010. Pengantar Administrasi Kesehatan Edisi 3. Jakarta: Binarupa Aksara

A Nasution, A Maulana, D Kurniawan. (2019). BERSAMA MEMAJUKAN DESA. Abdi Dosen:

Jurnal Pengabdian Pada Masyarakat 3 (2), 99-104

Chotimah, I., Oktaviani, S., \& Madjid, A. (2018). Evaluasi Program Tb Paru Di Puskesmas

Belong Kota Bogor Tahun 2018. PROMOTOR, 1(2), 87-95.

Chotimah, I., Anggraini, D. (2018). Pemberdayaan Masyarakat Melalui Peningkatan Kualitas

Pendidikan, Ekonomi, Kesehatan Dan Lingkungan. ABDIDOS 2 (1), 62-72.

Chotimah, I. (2017). Gambaran Perilaku Merokok Mahasiswa Universitas Ibn Khaldun Bogor 2013. HEARTY 5 (1).

Dinas Kesehatan Kabupaten Bogor. 2017. Profil Kesehatan Jawa Barat Tahun 2017. Bogor:

Dinas Kesehatan Kabupaten Bogor.

Dinas Kesehatan Provinsi Jawa Barat. 2016. Profil Kesehatan Jawa Barat Tahun 2016. Jawa Barat: Dinas Kesehatan Provinsi Jawa Barat.

Dwimawati, E., Yanuaringsih, G.P., Pangaribuan, R., ...Gurning, F.P., Pratama, M.Y. (2021). Smoke exposure at home to the incidence of pneumonia in children under 5 years old. Indian Journal of Forensic Medicine and Toxicologythis link is disabled, 2021, 15(1), pp. 1872-1878

Dwimawati, E., \& Anisa, N. (2018). Faktor-faktor yang berhubungan dengan pengetahuan kesehatan reproduksi remaja di SMK YAK 1 bogor kecamatan tanah sareal kota Bogor provinsi Jawa Barat tahun 2018. PROMOTOR, 1(2), 80-86.

D.N. Afiyani, E. Dwimawati, S. Pujiati. (2020). Gambaran Status Gizi Berdasarkan Antropometri Pada Mahasiswa Fakultas Ilmu Kesehatan Masyarakat Universitas Ibn Khaldun Bogor. PROMOTOR 3 (1), 50-55.

E. Dwimawati, F. Beliansyah, S.A. Zulfa. (2019). Pemberdayaan Masyarakat Melalui Pemanfaatan Teknologi Dalam Rangka Meningkatkan Kualitas Sumber Daya Manusia Di Desa Gunung Menyan. Abdi Dosen: Jurnal Pengabdian Pada Masyarakat 3 (1). Keputusan Menteri Kesehatan Republik Indonesia. (2007). 377/Menkes/SK/III/2007 Tentang Standar Profesi Perekam Medis dan Informasi Kesehatan. Jakarta

Fitrianingtyas, Pertiwi, dan Rachmania, W. Faktor-Faktor yang Berhubungan dengan Kejadian Kurang Energi Kronis (KEK) pada Ibu Hamil di Puskesmas Warung Jambu Kota Bogor. HEARTY Jurnal Kesehatan Masyarakat. 2018;6(2):1-8.

Kementerian Kesehatan Republik Indonesia. 2015. Rencana Strategis Kementerian Kesehatan

Tahun 2015-2019. Jakarta: Kementerian Kesehatan Republik Indonesia

Kementerian Kesehatan Republik Indonesia. 2018. Buletin Jendela Pusat Data dan Informasi. Jakarta: Kementerian Kesehatan Republik Indonesia

Kementerian Kesehatan RI. 2014. Peraturan Menteri Kesehatan RI Nomor 75 Tahun 2014 tentang Pusat Kesehatan Masyarakat. Jakarta: Kementerian Kesehatan

N. Oktaviani, I. Avianty, and E. D. Mawati, "Faktor-Faktor Yang Berhubungan Dengan Perilaku Merokok Pada Mahasiswa Pria Di Universitas Pakuan Bogor Provinsi Jawa Barat Tahun 2018," Promotor, vol. 2, no. 1, p. 44, 2019, doi: 10.32832/pro.v2i1.1788.

Novitasari, Y., Mawati, E. D., \& Rachmania, W. (2019). Faktor-Faktor Yang Berhubungan 
Dengan Perilaku Pemberian Asi Ekslusif Di Puskesmas Tegal Gundil Kota Bogor Jawa Barat Tahun 2018. PROMOTOR Jurnal Mahasiswa Kesehatan Masyarakat, 2(4), 324-333. https://doi.org/http://dx.doi.org/10.32832/pro.v2i4.2246.

Puskesmas Cibungbulang. 2017. Laporan Tahunan Puskesmas Cibungbulang. Bogor

Pertiwi, F. D., Hariansyah, M., \& Prasetya, E. P. (2019). FAKTOR RISIKO STUNTING PADA BALITA DIKELURAHAN MULYAHARJA TAHUN 2019. PROMOTOR, 2(5). https://doi.org/10.32832/pro.v2i5.2531

Pertiwi, F. D., Rahman, R. M., \& Lestari, D. W. (2018). Pemberdayaan masyarakat melalui bidang literasi di Desawaru Jaya. Jurnal ABDI DOSEN: Jurnal Pengabdian Pada Masyarakat, 2(2), 129-137. https://doi.org/10.32832/abdidos.v2i2.170

Sari MM, Nurkamila N, Mawati ED. Faktor-Faktor yang Mempengaruhi Kepatuhan Ibu Hamil dalam Melakukan Pemeriksaan Kehamilan di Puskesmas Cibungbulang Kabupaten Bogor Provinsi Jawa Barat Tahun 2018. Jurnal Mahasiswa Kesehatan Masyarakat [Internet]. 2018;1(2):96-103. Available from: http://ejournal.uikabogor.ac.id/index.php/PROMOTOR/article/view/1595

World Health Organizaton. 2017. Child Stunting Data Visualizations Dashboard. 